\title{
THE DEVELOPMENT OF ETHICAL GUIDANCE FOR MEDICAL PRACTITIONERS BY THE GENERAL MEDICAL COUNCIL
}

\author{
by
}

\author{
RUSSELL G. SMITH *
}

\section{INTRODUCTION}

In 1858 , legislation was enacted in Britain which created a statutory body entitled the General Council of Medical Education and Registration of the United Kingdom. ${ }^{1}$ This title, which was subsequently described by Viscount Addison in the House of Lords as "a cumbersome name" the initials of which "have often befogged many of us in the past", 2 and which was later abbreviated to General Medical Council ${ }^{3}$ or "GMC", contains reference to the two principal functions of the Council: on the one hand, the determination of whose name should be permitted to be placed upon the Medical Register, which it did by setting and monitoring educational standards for doctors; and, on the other hand, of whose name should be removed from the Register, which it did by holding judicial, disciplinary inquiries. In exercising both of these functions, the Council, by its constituent bodies and committees, indirectly became involved in the declaration of acceptable standards of professional conduct and medical ethics.

At present, the Council has a legislative power to provide advice to members of the profession on standards of professional conduct and medical ethics ${ }^{4}$ and this function is undertaken principally by the Council's Committee on Standards of Professional Conduct and on Medical Ethics, the "Standards Committee". This Committee is directly involved in the preparation and revision of the guidance given to all registered medical practitioners in the form of a small, thirty-two page, blue-covered booklet entitled Professional conduct and discipline: fitness to practise. ${ }^{5}$

* Russell G. Smith, BA(Hons.), LL.M., Dip.Crim.(Melb.), Ph.D.(Lond.), Lecturer, Department of Criminology, University of Melbourne, Parkville, Victoria, 3052, Australia.

This article is based on a paper presented at the Wellcome Institute for the History of Medicine's 'Symposium on the history of medical ethics', held in London on 7 December 1990.

\footnotetext{
${ }^{1}$ Medical Act 1858, 21 \& 22 Vict. c. 90, s. 3. For general information on the GMC see: C. F. Varlaam, 'The origins and development of the General Medical Council as a social-legal institution', Ph.D. thesis, University of London, 1978; M. Stacey, Regulating British medicine: the General Medical Council, Chichester, John Wiley, 1992; Irvine Loudon, Medical care and the general practitioner 1750-1850, Oxford, Clarendon Press, 1986; M. Jeanne Peterson, The medical profession in mid-Victorian London, Berkeley and London, University of California Press, 1978.

2 Parliamentary debates, House of Lords, 18 April 1950, 166: 913.

${ }^{3}$ See Medical Act 1950, 14 Geo. 6 c. 29, ss. 13, 34(1), 36(1).

${ }^{4}$ Pursuant to Medical Act 1983, c. 54, s. 35.

${ }^{5}$ GMC, Professional conduct and discipline: fitness to practise, London, The Council, February 1991.
} 
In the 1850s, however, when the GMC was first established, no such formal guidelines of good professional conduct existed, but, rather, they developed out of the decisions handed down by the Council in disciplinary cases decided over the years.

This paper will examine how this process of declaring acceptable standards of professional conduct by the use of decided cases developed, and will raise a number of problems which, arguably, it created in the nineteenth century and which continue to cause concern today.

\section{DISCIPLINARY JURISDICTION AND PROCEDURE IN THE NINETEENTH CENTURY}

The GMC's power to hold disciplinary inquiries into the professional conduct of practitioners originally derives from section XXIX, Medical Act 1858:

XXIX. If any registered medical practitioner shall be convicted in England or Ireland of any felony or misdemeanour, or in Scotland of any crime or offence, or shall after due inquiry be judged by the General Council to have been guilty of infamous conduct in any professional respect, the General Council may, if they see fit, direct the Registrar to erase the name of such medical practitioner from the Register.

The Medical Act 1858 came into operation on 1 October 1858 , and as early as June 1860 the Council was called upon to institute an inquiry under section XXIX. ${ }^{6}$ No specific procedure had been laid down by Parliament, save for an obligation to make "due inquiry" and, accordingly, the Council adopted a quasi-criminal procedure following the advice of its lawyers. This first attempt at a disciplinary inquiry, however, emphasized how difficult the jurisdiction was to administer as the practitioner successfully applied to the High Court following the erasure of his name from the Register, seeking its restoration on the grounds that he had been denied an opportunity of being heard. ${ }^{7}$

Following this unfortunate start, the Council appointed a Committee to prepare regulations for the hearing of proceedings under sections XXVI and XXIX, Medical Act $1858,{ }^{8}$ and these were adopted on 3 July $1861,{ }^{9}$ generally employing a judicial, adversarial, and quasi-criminal model of procedure.

Initially, the Council was composed of twenty-four members, ${ }^{10}$ who were all able to be involved in the hearing of disciplinary cases, and usually most members of the Council heard any given case. This contrasts with the position which obtained after 1950 when smaller committees were given jurisdiction to deal with disciplinary cases. ${ }^{11}$ Until 1926, members of the GMC were all medically qualified but in that year the first

\footnotetext{
${ }^{6}$ Case of R. Organ, GMC, Minutes, 11 August 1859, I: 69, 14 June 1860, I: 81, 15 June 1860, I: 83-4, 18 June 1860, I: 94-7, 19 June 1860, I: 103-4. Copies of the GMC's Minutes are held by the British Library and the University of London Library, Senate House.

${ }^{7}$ The Queen, on the prosecution of Richard Organ v. General Council of Medical Education and Registration of the United Kingdom (1861), $30 \mathrm{LJ}$ (QB) 201.

${ }^{8}$ GMC, Minutes, 1 July 1861, II: 20.

9 Ibid., 3 July 1861, II: 42-3.

${ }^{10}$ The history of the composition of the GMC is provided by M. Draper, 'Elections to the GMC', in GMC, Annual Report for 1979, London, The Council, 1980, p. 8.

11 See Medical Act 1950, s. 14, which created the Medical Disciplinary Committee, the forerunner of the present Professional Conduct Committee.
} 


\section{Russell G. Smith}

lay member was appointed to the Council $^{12}$ following a celebrated disciplinary case ${ }^{13}$ and, in part, owing to a concerted campaign by George Bernard Shaw to have a majority of lay members on the GMC. ${ }^{14}$ The function of lay members on the Council is essentially to act as disinterested members of the public who are able to represent the consumer interest in debates. However, when hearing disciplinary cases, a certain tension arises between their non-medical independence and their function as adjudicators of matters which sometimes require medical training and expertise.

Owing to the fact that GMC members who sit on disciplinary cases usually do not possess legal qualifications, a good deal of reliance is placed upon the lawyers who appear on behalf of the Council or complainant and the accused practitioner to ensure that cases are conducted in accordance with substantive and formal requirements of law. In the 1880 s, a practice developed of having not only the Council's solicitor present to conduct the case against the accused practitioner, but also a barrister to act as judicial assessor whose role it was to advise on questions of law and to rule on the admissibility and weight of testimony. The Legal Assessor has never, however, been formally involved in voting during the adjudication of cases but rather is limited to an advisory role. The first Legal Assessor to be present for a hearing, which took place on 26 April $1881,{ }^{15}$ was Henry Fielding Dickens, the son of Charles Dickens.

\section{DISCIPLINARY CASES 1858 TO 1883}

Between 1858 and 1883, registered medical practitioners were given no written guidance by the GMC as to how they should regulate their professional conduct so as to avoid disciplinary action. By reading reports of the early disciplinary cases in the medical and lay press, they could, however, have obtained some knowledge concerning the types of conduct which the GMC considered unacceptable. These included cases where practitioners had been convicted of criminal offences such as theft, ${ }^{16}$ fraud, ${ }^{17}$ forgery, ${ }^{18}$ perjury, ${ }^{19}$ abortion, ${ }^{20}$ indecent assault, ${ }^{21}$ attempted sodomy, ${ }^{22}$ and arson, ${ }^{23}$

12 The Rt. Hon. Sir Edward Hilton Young, GBE, DSO, DSC, MP, later Lord Kennet: GMC, Minutes, 27 November 1956, XCIII: 32 (a member from 23 May 1926 to 24 November 1931).

${ }^{13}$ Case of F. W. Axham, GMC, Minutes, 24 May 1911, xLVIII: 52-4.

14 G. B. Shaw, Doctors' delusions, London, Constable, 1931, pp. 47-8.

15 Case of S. Levenston, GMC, Minutes, 26 April 1881, xvIII: 68.

${ }^{16}$ Case of W. J. Cumming, GMC, Minutes, 6 November 1863, III: 329; The Times, 6 October 1863, p. 9d (convicted at the Middlesex Sessions of stealing a book, The Alpine guide, from a bookstall at King's Cross station).

${ }^{17}$ Case of D. De La C. Gourley, GMC, Minutes, 1 July 1861, II: 24; Central Criminal Court Cases, 1860, 52: 656 (convicted at the Central Criminal Court as an executor trustee defrauding an estate).

${ }_{18}$ Case of R. Wrixon, GMC, Minutes, 1 May 1863, II: 327; The Times, 27 February 1863, p. 12d (convicted at Reading of forging and uttering a cheque at the Star Hotel after going down from Exeter College, Oxford).

${ }^{19}$ Case of E. Thomas, GMC, Minutes, 1 May 1863, II: 327 (convicted at Liverpool of perjury).

${ }^{20}$ Case of J. C. White, GMC, Minutes, 16 April 1878, xv: 63-4 (convicted at Manchester Assizes of using instruments with intent to procure the miscarriage of Elizabeth Coy).

${ }^{21}$ Case of F. H. Morris, GMC, Minutes, 8 July 1871, Ix: 31; The Times, 31 March 1871, p. 11 (convicted at Devizes of unlawful and indecent assault of Sarah Gould, the 21-year-old housekeeper of a patient, $\mathrm{Mr}$ Hatt).

${ }^{22}$ Case of G. S. Symmons, GMC, Minutes, 11 May 1877, xIv: 91 (convicted at Liverpool of attempting to commit sodomy).

${ }^{23}$ Case of W. Story, GMC, Minutes, 5 July 1882, xIx: 86-7 (convicted at Bedford Assizes of setting fire to his house with intent to injure and defraud). 


\section{Ethical guidance of the GMC}

and cases where practitioners had been found guilty of infamous conduct in a professional respect involving such matters as covering unqualified assistants, ${ }^{24}$ committing adultery with patients, ${ }^{25}$ publishing an indecent work, ${ }^{26}$ improperly disclosing confidential details of a patient's condition, ${ }^{27}$ improperly using qualifications, ${ }^{28}$ and obtaining registration by fraudulent means. ${ }^{29}$

As a way of alerting practitioners to the extent and nature of unprofessional conduct, these cases were not altogether satisfactory for a number of reasons. First, only a limited range of issues presented themselves for adjudication by the Council and clearly not every type of misconduct was dealt with. For example, prior to 1883 , no practitioners had been found guilty of infamous conduct in a professional respect for advertising, canvassing, or depreciation of colleagues, although some complaints regarding such matters had been received. ${ }^{30}$ Indeed, on 27 November 1893, the Executive Committee of the Council was able to resolve that no rule at that time had been laid down by the GMC against advertising and that advertising in itself was not to be regarded as infamous conduct in a professional respect. ${ }^{31}$

Second, although some details of cases were reported in the GMC's Minutes, it was not until April 1864 that reporters were permitted entry to disciplinary proceedings, ${ }^{32}$ subject to a power to exclude them whenever the Council saw fit. The information publicly available to reporters was then extensively reported in the medical press with, for example, the GMC's President at the time, Dr Paget (later Sir George), claiming in 1874 that "the agency of the press, giving publicity to our debates and proceedings, has, I believe, more than doubled the powers of the Council". 33

\footnotetext{
${ }^{24}$ Case of D. B. Murdoch, GMC, Minutes, 4 July 1882, xIX: $70-6$ (guilty of covering an unqualified assistant, Colonel Griffin "the Black Doctor", following the death of two children treated by Griffin-not erased in view of undertaking given not to re-offend).

${ }^{25}$ Case of W. Hoar, GMC, Minutes, 18 March 1883, xx: 223-9; 20 April 1883, xx: 37 (erased for committing adultery with Mrs Stenning, the wife of a patient, Mr F. S. Stenning, following divorce proceedings).

${ }^{26}$ Case of S. La'Mert, GMC, Minutes, 26 May 1863, II: 158 (erased for publishing an indecent and unprofessional treatise 'Self preservation: a popular inquiry into the concealed causes of those obscure and neglected disorders of the generative system originating in certain solitary habits and youthful excesses, and terminating in nervous debility, impotence, sterility, indigestion, insanity, and consumption ...' and in having falsely pretended that his son, Lima La'Mert, was a joint author and publisher of the said treatise).

${ }^{27}$ Case of J. Pattison, GMC, Minutes, 5 July 1869, vil: 41-5; The Times, 21 January 1869, p. 11 b; Lancet, 1869 , i: 175-6, p. 212 (erased for improper disclosure of details of a patient's condition).

${ }^{28}$ Case of A. A. Sadgrove, GMC, Minutes, 20 April 1883, xx: 38, 24 April 1883, xx: 125-6; The Times, 16 January 1882, p. 10d, 17 January 1882, p. 11 e (erased for illegal and improper use of qualifications).

${ }^{29}$ Case of R. Organ, GMC, Minutes, 18 June 1860, I: 96-7, 19 June 1860, I: 103-104; (1861) LJ (QB) 201 (erased for endeavouring to obtain by fraudulent means a Diploma from the Royal College of Physicians of Edinburgh).

${ }^{30}$ Case of J. Lacey, GMC, Minutes, 4 March 1864, III: 398 (complaints received by Dr Styrap and Samuel Wood, Esq. respecting an advertisement published by $\mathrm{Mr}$ J. Lacey); Case of L. A. La'Mert, GMC, Minutes, 25 February 1868, vi: 306, 5 July 1869, vII: 46, 6 July 1869, vir: 49-50, 7 July 1869, viI: 57, 12 July 1869, vII: 121, 16 December 1869, vII: 3(Eng. Br.), 15 December 1870, vIII: 6(Eng. Br.) (complaints of advertising to be investigated).

${ }^{31}$ GMC, Minutes, 27 November 1893, xxx: 266.

32 GMC, Minutes, 26 April 1864, III: 16, and see Dr Andrew Wood's speech reported in Lancet, 1864, i: 501.

${ }^{33}$ GMC, Minutes, 9 July 1874, xI: 12-13; Lancet, 1874, ii: 64.
} 
It was likely, therefore, that considerable numbers of practitioners would not be aware of the GMC's views regarding particular types of conduct.

THE WARNING NOTICES 1883 TO 1914

During the 1870 s, the GMC started to deal with cases in which practitioners were charged with employing and covering unqualified assistants, and by 1883 the Council had considered nine such cases ${ }^{34}$ Of these, only one resulted in the charge being found proved although in that instance the practitioner's name was not erased from the Register. ${ }^{35}$

On 21 April 1883, following the adoption of a report by the GMC's Committee on the employment of unqualified assistants by registered practitioners, the Council made the following resolution:

That the Council record on its Minutes, for the information of those whom it may concern, that charges of gross misconduct in the employment of unqualified assistants, and charges of dishonest collusion with unqualified practitioners in respect of the signing of medical certificates required for the purposes of any law or lawful contract, are, if brought before the Council, regarded by the Council as charges of infamous conduct under the Medical Act. ${ }^{36}$

This, then, was the first formal indication which the GMC gave of the definition and scope of infamous conduct in a professional respect. On 20 November 1886, the Council resolved that "steps should be taken with a view of making public the above resolution", ${ }^{37}$ and this was subsequently carried out in July 1887 by inserting the above resolution twice in each of the leading medical journals. ${ }^{38}$

The Council continued to deal with cases of covering although it was not until November 1888 that practitioners' names were first erased from the Register for this

\footnotetext{
${ }^{34}$ Case of W. H. Kempster, GMC, Minutes, 5 July 1871, Ix: 17-20 (not guilty of covering William Goodson and issuing death certificates for him); Case of P. Fant, GMC, Minutes, 18 June 1875, xII: 32-3 (no action taken with respect to a complaint of covering Messrs Carr and Gisbourne); Case of D. B. Murdoch, GMC, Minutes, 4 July 1882, xIx: $70-6$ (guilty but not erased for covering Colonel Griffin); Case of T. Gray, GMC, Minutes, 8 March 1883, xx: 229-34, 24 April 1883, xx: 124-5 (not guilty but admonished for conviction of giving false death certificates and covering an unqualified assistant "Bell"); Case of G. T. May, GMC, Minutes, 27 June 1882, xIx: 204, 8 March 1885, xx: 252-3 (no action taken on complaint of giving false death certificates and covering "Butler"); Case of W. T , GMC, Minutes, 11 April 1876, XIII: 369-71 (no action taken on complaint of giving false death certificates and covering "B"); Case of $M$. Hillary, GMC, Minutes, 10 November 1882, xIx: 184-8 (no action taken on charge of covering Ethens De Tomanzie upon receipt of undertaking to cease employing De Tomanzie); and 4 July 1883, xx: 185 (Hillary removed to Michigan); Case of W. H. Dry, GMC, Minutes, 18 April 1883, xx: 256-60, 25 April 1883, xx: 127-9 (convicted of giving false death certificate but not erased for covering an unqualified assistant "Upfield"- -marked disapproval noted); Case of M. Healy, GMC, Minutes, 12 January 1883, xx: 157, 4 July 1883, Xx: 184-5, 28 March 1884, XxI: 61 (charge of covering Tomanzie and Games adjourned following the death of Healy in December 1883).

35 Ibid., Case of D. B. Murdoch.

${ }^{36}$ GMC, Minutes, 20 April 1883, xx: 91.

37 Ibid., 20 November 1886, XXIII: 152.

38 Ibid., 25 July 1887, XXIV: 402; Br. med. J., 1887, ii: 248 (30 July 1887 "Employment of unqualified assistants"); Lancet, 1887, ii: 229 (30 July 1887 "The General Council and irregular practice"); Medical Press and Circular, 1887, 95: 111 (3 August 1887 “The unqualified assistant"); Edinburgh Med. J., 1887, 33: 293 (September 1887 "Unqualified assistants").
} 


\section{Ethical guidance of the GMC}

offence ${ }^{39}$ In each case, however, the practitioners' names were restored to the Register after twelve months. ${ }^{40}$

Throughout the 1880s and 1890s, the Council continued to refine and elaborate upon its resolutions regarding the employment of unqualified assistants ${ }^{41}$ and by the turn of the century a formal Warning Notice was issued to all newly registered medical practitioners and, after 1920, reproduced in the front of the bound volumes of the Medical Register. ${ }^{42}$

By 1914, when the Warning Notices were revised and consolidated, they contained brief advice on questions of certification, employment of unqualified assistants, sale of poisons, association with unqualified persons, and advertising and canvassing. In addition, the Notices stressed that they did not refer to every possible type of professional misconduct and that circumstances could arise in which questions of professional misconduct fell outside the categories listed. ${ }^{43}$

The particular matters which were included in the Warning Notice arose directly out of disciplinary cases which had already been dealt with by the Council, and thus represented a distillation of the ethical principles which emerged from those cases. ${ }^{44}$ Thus, it was clear that the GMC was not a parliament for making professional laws ${ }^{45}$ and that "the Warning Notice was not in form a law or regulation made by the Council; it was merely a condensed statement of the successive judgments of the court". ${ }^{46}$ This point was emphasized in the early 1900 s when, following the issue of the Council's Warning Notice of 2 December 1901 with respect to the employment of unqualified pharmaceutical assistants, ${ }^{47}$ numerous practitioners objected to the GMC trying cases before declaring the offence illegal, and in 1903 the Council received a six page petition signed by 133 practitioners resident in Scotland objecting to the way in which the Council proceeded in the setting and monitoring of ethical standards of professional conduct. ${ }^{48}$ The Executive Committee of the Council replied, however, by issuing the following resolution:

The Executive Committee desire to point out that the General Council have no power to legislate or to issue resolutions binding upon the profession and having absolute

${ }^{39}$ Case of A. Lindsay, GMC, Minutes, 28 November 1888, xxv: 84-5 (erased for covering Edwin Middlebrooke); Case of S. J. Daly, GMC, Minutes, 29 November 1888, xxv: 88-90, 30 November 1888, XXv: 91-2 (erased for covering George Billing).

${ }^{40}$ Case of A. Lindsay, GMC, Minutes, 28 November 1889, xxvi: 156-9; Case of S. J. Daly, GMC, Minutes, 28 November 1889, xxvI: $161-3$.

${ }^{41}$ GMC, Minutes, 22 May 1888, xxv: 37-8; 26 May 1893, xxx: 64; 23 November 1897, xxxIv: 121-2.

42 The Warning Notice was only included in the Register between 1920 and 1958 following which Notes by the Disciplinary Committee were substituted until 1963 when the first Blue Pamphlet appeared.

${ }^{43}$ GMC, Minutes, 1 June 1914, LI: 54.

${ }^{44}$ See E. G. Little, 'The General Medical Council', The nineteenth century and after, 1926, DLXxxVIII: 149, p. 151; A. M. Carr-Saunders and P. A. Wilson, The professions, Oxford, Clarendon, 1933, p. 419.

${ }^{45}$ D. MacAlister, Introductory address on the General Medical Council: its powers and its work, Manchester University Press, 1906, p. 2.

46 Ibid., p. 12 and see, generally, on the evolution of the Warning Notice: GMC, Minutes, 1958, xcV: 211-31, Appendix VIII; W. Pyke-Lees, Centenary of the General Medical Council 1858-1958: the history and present work of the Council, London, Spottiswoode Ballantyne, 1958, pp. 9-13; and J. S. Happel, 'Advice on good practice from the Standards Committee', J. Med. Ethics, 1985, 11: 39-41.

${ }^{4}$ GMC, Minutes, 2 December 1901, xxxvil: 129-30.

48 GMC, Minutes, 6 January 1902, xxxıx: 278; 28 May 1902, xxxıx: 282; 3 June 1902, xxxıx: 100; 23 November 1903, XL: 249-53. 


\section{Russell G. Smith}

prohibitive effect. And in view of their judicial functions in particular cases of professional misconduct, it is not desirable to pass a resolution condemning any practice in general terms until a series of cases decided before them has so clearly demonstrated the prevalence of that practice as to call, in the opinion of the Council, for a Warning Notice to the profession. ${ }^{49}$

\section{PROBLEMS IN THE DECLARATION OF STANDARDS}

It now remains to consider whether or not the GMC's approach to the declaration of acceptable standards of professional conduct, namely, by the extraction of ethical principles from disciplinary cases and the issue of statements summarizing those principles after a series of cases has been disposed of, is the most efficient and effective way of proceeding.

\section{LAPSE OF TIME}

The first difficulty which, arguably, arises is that there was often a considerable lapse of time between the initial hearing of disciplinary cases relating to a particular matter and the appearance of the GMC's Warning Notice with respect to any given issue, Figure 1 depicts this problem diagrammatically. The vertical axis to this Figure shows the present range of disciplinary matters which are contained in the Blue Pamphlet, ${ }^{50}$ while time is indicated on the abscissa. For each type of conduct three dates are provided: the date upon which a disciplinary inquiry was first conducted (indicated by $\mathbf{a}$ ); the date upon which a practitioner's name was first erased from the Register for that type of misconduct (indicated by $\boldsymbol{\Delta}$ ); and the date upon which the GMC first issued its Warning Notice or Guidance with respect to that type of misconduct (indicated by 0 ).

Thus, for example, the first disciplinary inquiry involving a charge of covering was heard on 5 July $1871 ;^{51}$ the first instance in which a practitioner's name was erased from the Register for covering occurred on 28 November 1888 ; $^{52}$ while the GMC first issued its Warning Notice with respect to covering on 20 April $1883 .{ }^{53}$ In all but two types of case, namely those relating to drug prescription and drug abuse, the Council had dealt with cases and erased names prior to issuing its Warning Notices, with often many years transpiring in the interim period. A striking example relates to charges of breach of confidence, the first inquiry into which was held on 5 July $1869^{54}$ while the GMC did not issue its formal guidance on breach of confidence until 24 November $1970,{ }^{55}$ a lapse of some 101 years. In the case of drug offences, however, a different position obtained with guidance actually being issued some six months prior to the first disciplinary inquiry being held. The precise dates and periods of time involved for each type of conduct are presented in Table 1.

\footnotetext{
${ }^{49}$ GMC, Minutes, 23 November 1908, XLv: 224-5. College London, 1990, pp. 959-70, Appendix V.

${ }_{51}$ Case of W. H. Kempster, GMC, Minutes, 5 July 1871, IX: 17-20.

52 Case of A. Lindsay, GMC, Minutes, 28 November 1888, xxv: 84-5.

${ }^{53}$ GMC, Minutes, 20 April 1883, xx: 91.

${ }^{54}$ Case of J. Pattison, GMC, Minutes, 5 July 1869, viI: 41-5.

${ }^{55}$ GMC, Minutes, 24 November 1970, cVII: 29.
}

50 The precise definitions for these categories and the raw data from which the Figure is derived are contained in R. G. Smith, 'The professional conduct jurisdiction of the General Medical Council: its compliance with aspects of substantive and procedural justice', Ph.D. Thesis, Faculty of Laws, King's 


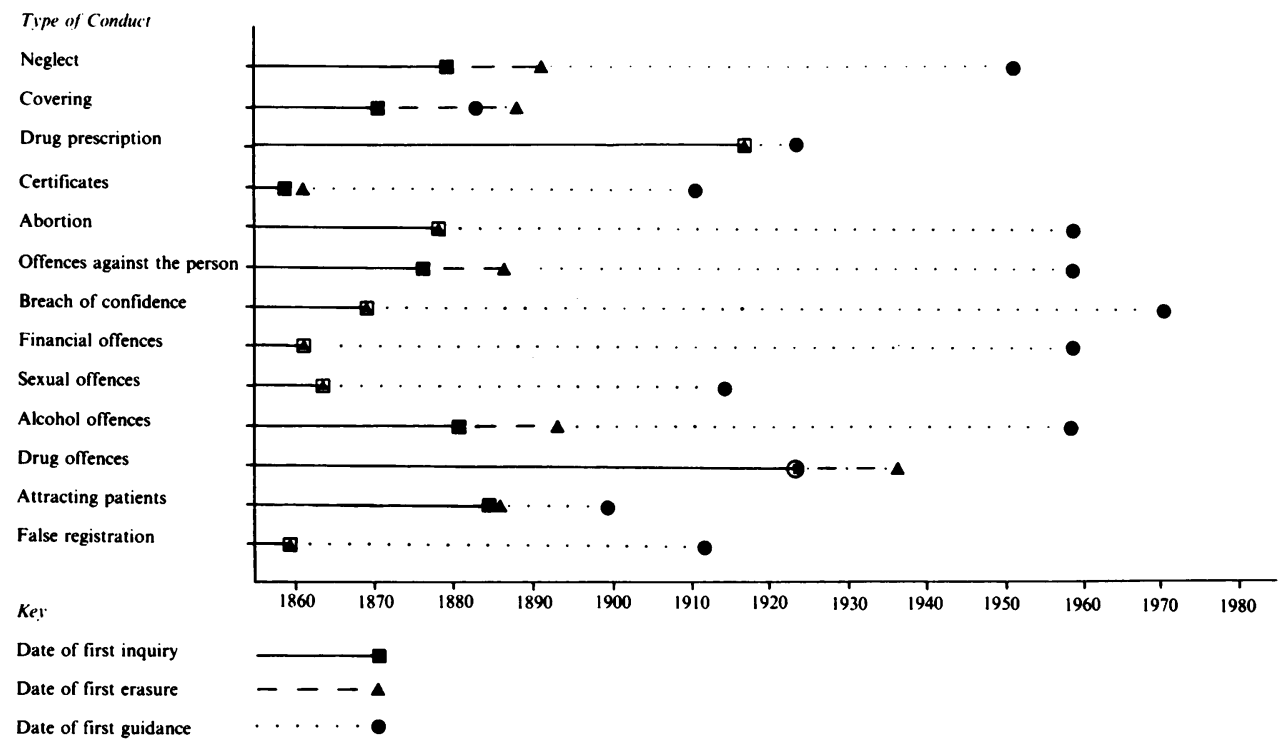

Figure 1: Time lapse between hearing of disciplinary cases and issue of guidance

Table 1: Dates of first inquiry, erasure and guidance for various types of conduct

\begin{tabular}{lrrrr}
\hline Type of conduct* & $\begin{array}{c}\text { Date of } \\
\text { first } \\
\text { inquiry } \\
\text { I }\end{array}$ & $\begin{array}{c}\text { Date of } \\
\text { first } \\
\text { erasure } \\
\text { E }\end{array}$ & $\begin{array}{c}\text { Date of } \\
\text { first } \\
\text { guidance } \\
\text { G }\end{array}$ & $\begin{array}{c}\text { Years } \\
\text { I-G }\end{array}$ \\
\hline Neglect & 5.3 .1879 & 25.11 .1891 & .7 .1951 & 73 \\
Covering & 5.7 .1871 & 28.11 .1888 & 20.4 .1883 & 12 \\
Drug prescription & 28.11 .1917 & 28.11 .1917 & 1.6 .1923 & 6 \\
Certificates & 3.10 .1859 & 10.5 .1861 & 30.11 .1911 & 52 \\
Abortion & 16.4 .1878 & 16.4 .1878 & 4.6 .1958 & 80 \\
Offences against the person & 5.6 .1876 & 27.11 .1888 & 4.6 .1958 & 82 \\
Breach of confidence & 5.7 .1869 & 5.7 .1869 & 24.11 .1970 & 101 \\
Financial offences & 1.7 .1861 & 1.7 .1861 & 4.6 .1958 & 97 \\
Sexual offences & 26.5 .1863 & 26.5 .1863 & 1.6 .1914 & 51 \\
Alcohol offences & 8.7 .1880 & 24.55 .1893 & 4.6 .1958 & 78 \\
Drug offences & 28.11 .1923 & 25.11 .1936 & 1.6 .1923 & -6 mnths \\
Attracting patients & 20.11 .1884 & 19.5 .1885 & 6.6 .1899 & 15 \\
False registration & 16.5 .1859 & 16.5 .1859 & 30.11 .1911 & 52 \\
\hline
\end{tabular}

* Medical Act 1858, section XxIX, cases of conduct and conviction only

Although the GMC has always stated that the matters dealt with in the Warning Notice were not to be taken as an exhaustive list, ${ }^{56}$ practitioners could, arguably, feel that they had been proceeded against before the conduct in question had been professionally proscribed. ${ }^{57}$

\footnotetext{
${ }^{56} \mathrm{Op}$. cit., note 43 above.

57 See discussion above, note 48 .
} 


\section{Russell G. Smith}

\section{AbSENCE OF EXPLANATION}

The second difficulty which arises relates to the fact that the GMC has always maintained a strict policy of not elaborating upon or explaining the matters contained in the Warning Notice because its judicial function is perceived as being inconsistent with an advisory role. Accordingly, practitioners who contemplate embarking upon a course of action which may potentially bring them within the GMC's disciplinary remit, are unable to ascertain in advance whether or not the proposed action will or will not be viewed by the GMC as unprofessional. This problem continues to cause concern today. For example, one practitioner who was dealt with in 1983 for issuing prescriptions for controlled drugs other than in the course of bona fide treatment, was informed by the GMC in response to her request for guidance about the treatment of drug addict patients in private practice, prior to embarking upon such treatment, that "the Council has hitherto issued no specific guidance on that subject". 58

Even when disciplinary proceedings have begun, practitioners may feel that the GMC has been disingenuous in identifying the precise objections to the practitioner's conduct. For example, one practitioner wrote to the GMC's solicitor on 26 June 1895 seeking an explanation as to why he had been charged with publishing and circulating a book entitled Electro-homoeopathic medicine: "I am left entirely in the dark as to what kind of objections are found by the General Medical Council in these passages, and how I am to answer them". 59

\section{Dissemination OF GUIDANCE}

In order for the GMC to fulfil its role of setting and maintaining professional standards, it is essential that its proceedings and debates be widely disseminated and brought to the attention of all registered practitioners. As already mentioned, ${ }^{60}$ the GMC's debates prior to 1864 were closed to members of the public, including registered practitioners other than members of the Council, and it was only after a concerted campaign by one GMC member, Dr Andrew Wood, in the 1860 s, $^{61}$ that press reporters were finally permitted to report certain parts of the GMC's debates. The early reports of proceedings in the GMC's Minutes as well as the medical and lay press were quite extensive and, for example, in 1879 a report of the executive Committee on the constitution and working of the GMC was able to conclude that "the admission of reporters has made the profession fully cognisant of the proceedings and debates, which have for the most part been published at length in the medical journals". 62

Unfortunately, over the 135-year history of the GMC's existence, there has been a steady decline in the extent to which information is reported with respect to the GMC's activities. If practitioners are expected to refrain from the commission of

\footnotetext{
${ }^{58}$ See: A. Dally, A doctor's story, London, Macmillan, 1990, p. 113, and R. Smith, 'Serious professional misconduct arising out of the treatment of drug addiction', Professional Negligence, 1990, 7: $33-6$.

${ }^{59}$ Case of R. M. Theobald, GMC, Minutes, 22 July 1895, XXXII: 194. See also P. S. Brown, 'Medically qualified naturopaths and the General Medical Council', Med. Hist., 1991, 35: 50-77.

60 See above, note 32 .

${ }^{61}$ See Dr Andrew Wood's speech on the need for publicity reported in Lancet, 1864, i: 501 .

62 GMC, Minutes, 18 March 1879, xvI: 24.
} 


\section{Ethical guidance of the GMC}

professional misconduct, then it is essential that they be provided with reasonably full and adequate reports of instances in which their professional colleagues have fallen foul of the GMC's professional conduct jurisdiction.

\section{INTERPRETATION AND APPLiCATION OF GUIDANCE}

A number of serious difficulties exist in relation to the extraction of accurate, consistent, and workable ethical principles and rules of practice from decided cases, and also with respect to the interpretation of the GMC's guidance.

\section{Absence of reasoned decisions}

The Medical Act 1858 originally only gave the General Council power to direct the Registrar to erase the name of a practitioner from the Register, ${ }^{63}$ and the early Standing Orders which regulated disciplinary procedure merely specified the form of resolutions to be voted upon with respect to whether or not a conviction was proved, whether or not the offence amounted to infamous conduct in a professional respect, and whether or not a direction for erasure should be given. ${ }^{64}$ As such, there was little scope for the President to make comments or give reasons for decisions, although by 1932, the Standing Orders provided for the announcement of decisions by the President together with "such terms of reprimand, admonishment or otherwise as the Council shall approve". ${ }^{65}$ In the case of Dr Theobald, whose name had been erased in 1894 for publishing a book on homoeopathy, ${ }^{66}$ the practitioner had requested a rehearing on the grounds, inter alia, that the Council had failed to give reasons for its decision. ${ }^{67}$ The GMC's solicitor, Mr Farrer, however, confirmed that the Council "does not give reasons for or explain its decisions". 68

This practice seriously detracts from the ability of the accused practitioner, other medical practitioners, and members of the public to understand and interpret the GMC's ethical determinations. The failure to give reasoned decisions may well leave the profession in some doubt as to what behaviour constitutes professional misconduct and what particular sanctions have been imposed. In addition, if reasoned decisions were given, the appeal process would be greatly strengthened because the appellate body would know precisely what facts have been found proved, what view GMC members took regarding conflicting evidence, and what particular considerations were taken into account in mitigation or aggravation as affecting the choice of a particular sanction.

Some of the arguments which have been raised against the giving of reasoned decisions include the possibility that individual GMC members would differ on the reasons given, and so it would be difficult to prepare a reasoned decision with which everyone agreed in sufficient time to be delivered at the conclusion of the hearing, and that the preparation of such a decision would entail drafting by the Legal Assessor

\footnotetext{
${ }^{63}$ Section XXIX.

${ }^{64}$ Standing Orders 1885 , chap. 12, para. 13 reproduced in GMC, Minutes, 19 November 1885, xxII: 179-80.

${ }^{65}$ Standing Orders 1932, chap. 14, para. 9 reproduced in GMC, Minutes, 1932, LXIX: 343, Appendix XI.

${ }^{66}$ Case of R. M. Theobald, GMC, Minutes, 3 December 1894, XXXI: 159-60.

${ }^{67}$ Ibid., GMC, Minutes, 22 July 1895, XXXII: 195.

68 Ibid., 22 July 1895, XXXII: 195.
} 


\section{Russell G. Smith}

with whose views everyone might not agree. ${ }^{69}$ In addition, there is the fear that the introduction of reasoned decisions would open the floodgates to all kinds of excessively legalistic and technical arguments, and would lead to decision-makers being obliged to have regard to prior decisions as precedents. As will be argued presently, the emergence of a jurisprudence based on prior decisions could be seen as a wholly worthwhile trend to be encouraged.

On balance, it appears that the arguments advanced in support of the obligation to give reasoned decisions outweigh those against and it is clear that the GMC's function of declaring ethical principles of good professional conduct would be enhanced if reasoned decisions were given in disciplinary cases.

\section{Ad hoc cases}

A further difficulty with using disciplinary cases to declare principles of professional conduct is that the cases which result in public hearings tend to be ad hoc, disparate, and relate to their own peculiar factual circumstances. From the earliest times, the GMC has emphasized that it will not act as a police force for the profession in respect of discovering instances of misconduct, ${ }^{70}$ but rather, cases are brought to the attention of the Council by independent public authorities, such as the courts, or by individual complainants such as colleagues or patients. Many factors are responsible for prompting individuals or bodies to report cases to the Council although generally dictates of fashion and topicality are important and these often follow closely new legislative reforms and contemporary social events or medical developments. For example, the occurrence of wars and changes in immigration patterns, and medical matters such as the introduction of vaccination, employment of medically unqualified assistants, the introduction of midwives, developments in cosmetic surgery, and problems of alcohol and drug abuse have all been associated with the incidence of cases of misconduct being reported.

In addition, once cases are notified to the Council, a filtering process takes place in which the vast majority of complaints are excluded as being unsuitable for public hearing or as not raising questions of misconduct within the jurisdiction of the Council. Accordingly, only a highly limited and selective range of issues is adjudicated publicly and it is only these which generally form the basis of the Council's ethical guidance.

\section{Absence of precedent}

The third problem, already adverted to, is that the Council has almost never relied upon the doctrine of precedent in deciding cases but considers each new case in isolation and without reference to cases of a similar nature which have arisen in the past. The reasons for this relate primarily to the absence of detailed reasons being given in cases, the fact that decisions are given extempore, and that decision-

\footnotetext{
${ }^{69}$ See: Report of the committee of inquiry into the regulation of the medical profession (Chairman: Dr A. W. Merrison), London, HMSO, Cmnd. 6018, 1975, p. 106, para. 309.

${ }^{70}$ GMC, Minutes, 16 May 1862, II: 94-5; 27 June 1882, xIx: 17; 22 May 1888, xxv: 18; 1926, LxIII: 268, Appendix IV; 3 June 1969, CVI: 9; 2 June 1970, CVII: 7; 1973, CX: 186-7, Appendix III.
} 


\section{Ethical guidance of the GMC}

makers change frequently. Thus, as the Lancet observed in discussing the case of Dr Tarnesby in 1969,

an evolving system of case law such as that from which our common law continues to develop is not to be extracted from the records of the Committee; and a lawyer, seeking to establish from these a coherent pattern, is likely to withdraw baffled. ${ }^{71}$

As a means of creating an ongoing body of ethical principles and practical guidelines which have emerged from individual cases, the system which has evolved is not altogether satisfactory in this regard.

Generally, then, for these reasons, it is, arguably, both inefficient and ineffective to attempt to declare ethical principles and guidelines for professional conduct through the analysis of prior disciplinary decisions of the Council and its Committees.

Finally, it seems to be unfair to require individual practitioners to undergo emotionally and financially burdensome disciplinary proceedings in order for general ethical and professional principles to be declared which will be of benefit and use to the whole professional community. Rather, disciplinary proceedings should only be used once the principles and guidelines have been established and alleged breaches of them identified.

\section{LESSONS FROM THE PAST}

In many respects the GMC's professional conduct jurisdiction is little different today from the penal jurisdiction of the nineteenth century. However, as already mentioned, one important difference is the fact that the Council has now a legislative power to provide advice to members of the profession on standards of professional conduct and medical ethics. In addition, the GMC is attempting to improve relations between itself, the profession, and the public by, for example, the appointment of a Press Officer and the provision of explanatory notes to members of the public in hearings.

Rather than perpetuating the manner in which ethical principles were extracted and declared in the nineteenth century, it would, arguably, be preferable for the Council's Standards Committee to declare principles of professional conduct and ethics in novel areas of medical practice in advance of the Council embarking upon disciplinary inquiries. In addition, there seem to be good reasons for the Council actively to offer advice to practitioners with respect to the scope and meaning of its guidance and to advise practitioners with respect to the acceptability or otherwise of given conduct. Finally, it seems that those involved in decision-making within the GMC should show a greater willingness than they do at present to make use of precedent and to give reasoned decisions in cases.

${ }^{71}$ Case of H. P. Tarnesby, Lancet, 1969, ii: 305. 